\title{
TRADISI NAHDLATUL ULAMA DALAM PERSPEKTIF HUKUM ISLAM
}

\author{
Ahmad Zulfikri \\ ahmadzfikri99@gmail.com \\ Institut Agama Islam Negeri Kudus \\ Ashif Az Zafi \\ ashifazzafi@iainkudus.ac.id \\ Institut Agama Islam Negeri Kudus
}

DOI: $10.21580 /$ wa.v7i1.5504

\begin{abstract}
One of the issues in the country of Indonesia is the existence of religious traditions considered a religious tradition that is contrary to Islamic law and is not in accordance with the sunnah of the Holy Prophet. This issue is a serious problem and must be explained through arguments in accordance with the implementation of traditions carried out by Nahdliyyin citizens in Indonesia. And legal evidence must be found for the permissibility of carrying out these traditions. According to modernists these traditions are heretical and must be abandoned by society. As a social and religious organization, Nahdlatul Ulama must have a tendency for carrying out its traditions in the Qur'an and asSunnah. Through this article the author reviews how the perspective of Islamic law regarding the implementation of the religious traditions of Nahdliyyin citizens and some examples of religious traditions that are often performed by Nahdliyyin residents.
\end{abstract}

Keywords: Tradition, Religion, Nahdlatul Ulama, Islamic Law

\begin{abstract}
Abstrak
Salah satu isu di negara Indonesia adalah keberadaan tradisi keagamaan dianggap sebuah tradisi keberagamaan yang bertentangan dengan hukum Islam dan tidak sesuai dengan sunnah Nabi saw. Isu ini adalah masalah yang serius dan harus dijelaskan melalui dalil-dalil yang sesuai dengan pelaksanaan tradisi yang dilakukan oleh warga Nahdliyyin di Indonesia. Dan harus ditemukan dalil
\end{abstract}


hukmi atas diperbolehkannya melaksanakan tradisi tersebut. Menurut kaum modernisme tradisi-tradisi ini termasuk bid'ah dan harus ditinggalkan oleh masyarakat. Sebagai organisasi kemasyarakatan dan keagamaan, Nahdlatul Ulama haruslah mempunyai tendensi atas pelaksanaan tradisinya dalam AlQur'an dan as-sunnah. Melalui artikel ini penulis mengulas bagaimana perspektif hukum Islam tentang pelaksanaan tradisi-tradisi keagamaan warga Nahdliyyin dan beberapa contoh tradisi keagamaan yang sering dilakukan warga Nahdliyyin.

\section{Kata kunci: Tradisi, Keberagamaan, Nahdlatul Ulama, Hukum Islam}

\section{A. Pendahuluan}

Sejak awal abad ke-20 banyak bermunculan organisasi kemasyarakatan dan organisasi keagamaan di Indonesia. Organisasi kemasyarakatan tersebut mempunyai tujuan yang sama, yaitu menyatukan rakyat Indonesia untuk melawan penjajah dan mempertahankan keimanan rakyat Indonesia. Diantara organisasi yang didirikan pada masa tersebut adalah Nahdlatul Ulama atau sering disebut NU, yang didirikan oleh ulama terkenal dengan keilmuan agamanya di Indonesia yaitu hadratusy syekh $\mathrm{KH}$. Hasyim Asy'ari beserta ulama-ulama lain di Indonesia. Mereka bersatu membentuk organisasi kemasyarakatan dengan semangat juang melawan penjajah Belanda dan Jepang di Indonesia dan merebut kemerdekaan dari mereka. Nahdlatul Ulama (NU) adalah organisasi yang masih eksis sampai sekarang dan menjadi salah satu organisasi Islam terbesar di Indonesia. Nahdlatul Ulama (NU) juga memiliki beberapa cabang istimewa yang berada di beberapa negara di penjuru dunia.

Nahdlatul Ulama (NU) merupakan organisasi yang memiliki hubungan erat dengan pesantren yang merupakan cikal bakal dari kelembagaan NU sebagai organisasi keberagamaan. Komunitas NU mempunyai kehidupan masyarakatnya yang sangat menjunjung tinggi tradisi kebudayaan nusantara dalam kehidupan sehari-harinya. Praktek keberagamaan komunitas NU dalam kesehariannya lazim disebut dengan amaliyah nahdliyah yang prakteknya menggunakan pedoman Al-Qur'an dan Hadits sebagai sumber ajaran umat Islam. Praktek konkrit dari ajaran-ajaran dalam Al-Qur'an dan Hadits dapat dilihat pada praktek keberagamaan masyarakat baik bersifat sosial, budaya ataupun yang lainnya. Tradisi sosial budaya warga NU merupakan contoh konkrit dari praktek keberagamaan umat Islam Indonesia. Fenomena tersebut tidak bisa dihilangkan dalam kehidupan umat Islam Indonesia karena merupakan esensi dari ajaran Islam sendiri. Oleh karena itu muncullah permasalahan mengenai bagaimana pandangan hukum Islam pada praktek tradisi keberagamaan umat Islam Indonesia. Adanya unsur kebudayaan, adat istiadat dan tradisi merupakan kerangka dasar dalam pelaksanaan nilai-nilai keislaman dalam kehidupan. Dalam masalah ini terdapat dua unsur yang dapat dijadikan acuan yaitu unsur din dan tadayun. Din merupakan keseluruhan ajaran agama Islam, kitab suci AlQur'an dan Hadits sebagai pedoman umat Islam dalam beragama dan nilai-nilai ajaran agama Islam. Unsur yang kedua yaitu tadayun yang merupakan bentuk keberagamaan dan 
realisasi ajaran agama Islam dalam sehidupan sehari-hari. Substansi dari ajaran agama dalam Al-Qur'an dan Hadits dimasukkan dalam praktek kehidupan sosial dan tradisi kebudayaan yang sudah ada sebelumnya dan menghasilkan tradisi baru yang berpegang teguh pada ajaran agama Islam. ${ }^{1}$

Pada praktek pelaksanaan tradisi keberagamaan NU dalam lingkup masyarakat, tak jarang ada pertentangan dengan ormas-ormas lain di Indonesia. Banyak yang mengatakan bahwa tradisi-tradisi yang dilakukan warga Nahdlatul Ulama (NU) adalah bid'ah dan tidak sesuai dengan ajaran Al-Qur'an dan sunnah Nabi. Sekelompok dari mereka justru ada yang menganggap tradisi keislaman warga $\mathrm{NU}$ adalah perilaku sesat dan bertentangan dengan ajaran Al-Qur'an dan sunnah. Tradisi-tradisi tersebut dianggap seperti tradisi yang dilakukan orang Hindu-Budha pada jaman sebelum Islam masuk di bumi nusantara, yang dulunya mempercayai roh-roh halus sebagai makhluk yang bisa mendatangkan keberuntungan maupun kesengsaraan. Mereka sangat menentang tradisi-tradisi keberagamaan yang dilakukan warga Nahdlatul Ulama' (NU), padahal tradisi-tradisi tersebut telah ditelaah oleh ulama-ulama NU dan telah mendapatkan dalil-dalil yang menyatakan diperbolehkannya melaksanakan tradisi-tradisi yang telah dilakukan warga Nahdlatul Ulama dalam kesehariannya.

Pembahasan mengenai hukum mengamalkan tradisi-tradisi warga Nahdliyyin sering diperbincangkan dalam artikel-artikel ilmiah, ceramah-ceramah agama maupun media yang lain. Perbincangan ini sangatlah menarik karena adanya perselisihan pendapat tentang pelaksanaan tradisi keberagamaan ini. Budaya sangatlah berpengaruh pada keberadaan tradisi keberagamaan masyarakat NU ini. Kebanyakan tradisi keberagamaan warga Nahdliyyin mengadopsi dari dakwah walisongo sebagai pembawa ajaran Islam pertama di tanah Jawa.

Penulisan artikel ini bertujuan untuk menjawab berbagai rumusan masalah yang muncul dan melatarbelakangi penulisan artikel ini. Problematika yang muncul daikalangan masyarakat modern tentah kebid'ahan amaliyah-amaliyah warga Nahdliyin dalam melaksanakan tradisi keberagamaan yang telah disusun rapi dan dilaksanakan dikehidupan sehari-harinya. Diharapkan para masyarakat setelah membaca artikel ini, bisa memahami dan mengubah pola pikirnya tentang hukum Islam dalam tradisi yang dibilang bid'ah dan tidak perlu dilestarikan dalam bermasyarakat. Perlu diketahui bahwa tradisi-tradisi keberagamaan ini telah dikaji dan didiskusikan oleh para ulama-ulama yang ahli pada bidangnya masing-masing. Diharapkan, setelah membaca artikel ini tidak mudah mengatakan bahwa tradisi-tradisi keberagamaan tersebut adalah bid'ah. Kebid'ahan dalam tradisi-tradisi ini tentunya merupakan bid'ah yang baik dan tidak masuk pada pengertian bidah yang bersifat sesat. Pada intinya dalam menentukan hukum suatu perkara itu harus mengkaji dari sumber ajaran Islam, yaitu Al-Qur'an dan Hadits, serta mengambil hukum melalui ijma' para ulama dan menqiyaskan suatu perkara yang belum termaktub dalam AlQur'an maupun Sunnah Rasulullah saw dengan hukum yang sudah jelas ada dalam sumber ajaran agama Islam.

${ }^{1}$ Muslim A Kadir, Ilmu Islam Terapan, (Yogyakarta: Pustaka Pelajar, 2013), hlm. 6 


\section{B. Pembahasan}

\section{Keberagamaan Tradisi Nahdlatul Ulama}

Konsep keberagamaan merupakan hal yang perlu diketahui dalam menjelaskan perilaku keagamaan umat Islam. Keagamaan berasal dari akar kata agama yang merujuk pada wahyu ketuhanan sebaga pedoman kehidupan umat Islam guna mendapatkan kebahagiaan di dunia dan di akhirat. Keberagamaan adalah bentuk kata kerja dari akar kata beragama yang memiliki substansi berupa bentuk aktivitas dan pengamalan ajaran-ajaran agama dalam kehidupan umat Islam dalam kesehariannya. Keberagamaan dapat dibedakan menjadi dua jenis, yaitu hubungan Rasul sebagai sang penerima wahyu Tuhan dan sekelompok orang yang beriman yang mengamalkan wahyu tersebut dalam kehidupan sehari-hari yang sesuai dengan ajaran agama Islam. ${ }^{2}$ Dari hal tersebut dapat disimpulkan bahwa keberagamaan adalah suatu hal yang dikhususkan bagi umat yang beriman dalam mengamalkan ajaran agamanya dibandigkan pada kelompok masyarakat pada umumnya. Posisi orang beriman dalam konsep keberagamaan ini adalah sebuah unit sosial yang memiliki ciri khas tersendiri dalam mengamalkan ajaran agama mereka dan bertumpu pada jati diri mereka sendiri.

Nahdlatul Ulama adalah sebuah organisasi keagamaan Islam (jam'iyah diniyah Islamiyah) yang bergerak dibidang pendidikan, sosial, agama dan ekonomi. Sebagai organisasi kemasyarakatan yang bernaung dibidang agama pada khususnya, NU memiliki prinsip-prinsip dasar untuk memahami ajaran agama Islam baik mengenai hubungan vertikal dengan Allah maupun hubungan horizontal antar sesama manusia. NU mendasarkan pemahaman keagamaan yang bersumber dari sumber ajaran agama Islam, yaitu Al-Qur'an, Hadits, ijma' para ulama, dan qiyas. NU merupakan suatu ormas keislaman yang mendasarkan pemikirannya pada paham ahlussunnah wal jamaah (Aswaja). Dalam menjalankan ibadah kesehariannya warga NU menganut pada salah satu dari empat imam mazhab yaitu Imam Abu Hanifah, Imam Malik, Imam Muhammad bin Idris AsySyafi'i dan Imam Ahmad bin Hambal. Keempat imam besar tersebut memiliki mazhab tersendiri dan juga sering dijumpai perbedaan pendapat mengenai hukum suatu masalah fiqih. Pada bidang akidah, NU mengikuti paham yang dibawakan oleh Abu Hasan alAsyari dan Abu Mansur Almaturidi. Dalam bidang tasawuf mengikut pada Al-Junaidi AlBaghdadi dan Abu Hamid Al-Ghozali. Ulama-ulama tersebut sangat alim dan mendalami ilmunya dan sangat masyhur keilmuannya di dunia keislaman. ${ }^{3}$

Dalam menjalankan tradisi keislamannya warga Nahdlatul Ulama (NU) menganut kaidah yang sangat populer yaitu:

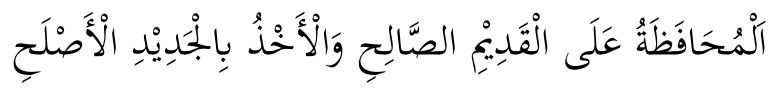

${ }^{2}$ Muslim A. Kadir, Dasar-Dasar Keberagamaan Dalam Islam, (Yoyakarta: Pustaka Pelajar, 2011), hlm. 55

${ }^{3}$ Ahmad Zahro, Tradisi Intelektual NU, (Jakarta: LkiS, 2004), hlm. 19 


\section{"Memelihara nilai-nilai dahulu yang baik dan mengambil nilai-nilai baru yang lebih baik"4}

Kaidah tersebut diterapkan dalam kehidupan warga NU dengan mempertahankan nilai-nilai terdahulu yang dapat diterapkan dalam keseharian umat Islam. Warga Nahdlatul Ulama atau sering disebut masyarakat Nahdliyyin dengan gigih mempertahankan tradisi yang telah berkembang dimasyarakat. Praktek tersebut dapat dilihat pada keseharian warganya, berupa kegiatan mauludan atau pembacaan al-Barzanji (berisi syair dan pujian kepada Nabi Muhammad SAW. dan kisah kehidupan beliau), tahlilan (serangkaian kalimat-kalimat tayibah dan bacaan sepenggalan ayat suci Al-Qur'an yang disusun sedemikian rupa sehingga tersusun rapi dan dibacakan kepada orang yang sudah meninggal), dan yasinan (pembacaan surat Yasin di waktu-waktu tertentu). Tradisi-tradisi NU ini masih dipertahankan dan terus diamalkan dalam keseharian warga Nahdliyyin. Sedangkan pengertian mengambil dan memanfaatkan nilai-nilai yang baru adalah menerapkan dan mengembangkan nilai-nilai tersebut sehingga relevan dan sesuai dengan ajaran agama Islam dan dapat diterapkan pada kehidupan di zaman sekarang. Dengan cara seperti itu nilai-nilai yang sudah diwariskan ulama terdahulu dapat dikontekstualisasikan dalam kehidupan masyarakat dan sesuai dengan kehidupan masyarakat pada masa ini. Banyak kaum modernisme yang mengaggap tradisi-tradisi warga Nahdliyyin sebagai bid'ah dan tidak perlu dilestarikan. ${ }^{5}$

Dalam kehidupan masyarakat Nahdliyyin erat kaitannya dengan kehidupan pesantren yang didalamnya mencerminkan kehidupan keberagamaan yang dilakukan warga NU. Hal ini karena asal muasal organisasi NU yang lahir dari lingkungan pesantren dan didirikan oleh ulama-ulama yang menerapkan pribumusasi Islam dalam keberagamaan umat Islam Indonesia. Pada konsep pribumisasi Islam ini sumber ajaran Islam, yaitu AlQur'an dan Hadits dipadukan dengan kehidupan sosio-kultural warga lokal. ${ }^{6}$ Tentunya amaliyah-amaliyah warga NU merupakan amaliyah yang ada tuntunan dalam menjalankan amaliyah tersebut dalam Al-Qur'an maupun Sunnah Nabi saw. Walaupun begitu masih terdapat pertentangan dari ormas-ormas lain mengenai hukum melaksanakan tradisi-tradisi yang dilakukan warga Nahdliyyin. Tetapi, perbedaan ataupun pertentangan tersebut hanyalah pada masalah-masalah furu'iyah saja, dan tidak sampai merusak aqidah umat Islam. Meskipun perbedaan tersebut hanya pada masalah furu'iyah, bukan berarti bahwa pertentangan tidak menjadi keras. Bahkan mereka menganggap tradisi-tradisi atau amaliyah yang dilakukan masyarakat NU adalah perbuatan bid'ah, dan mengamalkan takhayul, khufarat, dan bid'ah. Rivalitas atau pertentangan tersebut tapi hanya menyentuh pada dimensi kaum elit saja karena ternyata di kalangan kaum awam rivalitas itu sangat jarang dijumpai. Rasa solidaritas dan kesatuan dikalangan mereka sangat dijaga dengan baik. Terbukti dikalangan awam, mereka tidak saling mempersalahkan apa dan bagaimana tindakan keagamaan masing-masing kelompok. Jadi dapat disimpulkan bahwa rivalitas

\footnotetext{
${ }^{4}$ Ibid., hlm. 21

${ }^{5}$ Ibid., hlm. 23

${ }^{6}$ Ahmad Zahro, Ibid., hlm.25
} 
tersebut merupakan masalah pada kaum elit yang memang memiliki kesadaran identitas yang sangat tinggi. ${ }^{7}$

\section{Tradisi Dalam Perspektif Hukum Islam}

Relasi antara tradisi dan hukum melaksanakan tradisi tersebut menurut hukum Islam, yang mana hukum Islam tersebut didapatkan dari Al-Qur'an, Hadits, dan melaui ijma' para ulama serta qiyas dan tradisi adalah tradisi masyarakat Nahdliyyin sebagai pengamaldan pelaksana hukum Islam tersebut. Keberadaan hukum Islam ini adalah bagian atau komponen ajaran agama Islam yang kemudian diamalkan oleh orang yang beriman. Keberadaan tradisi warga NU adalah perangkat pelaksanaan yang merupakan bentuk keberagamaan sebagai pelaksana ajaran agama tersebut. Dengan hal ini komponen hukum sebagai tolak ukur perspektifitas nilai-nilai tradisi dalam masyarakat tidak lain adalah mengukur hubungan antara substansi ajaran agama denagn wujud pelaksanaannya dalam kehidupan konkret. Dalam masalah ini rumusan relasional dalam perspektivitas tersebut mengukur kandungan serta isi ajaran agama yang bersifat universal dengan praktek keberagamaan yang pelaksanaannya mengacu pada ruang dan waktu. Dalam hal ini masyarakat Nahdliyyin sebagai subyek pelaksana tradisi yang dibatasi pada ruang dan waktu.

Pengertian tradisi berasal dari bahasa Inggris tradition yang diartikan seperti al'adah dan 'urf dalam bahasa Arab, yaitu berupa perilaku maupun kegiatan yang dilakukan sehari-hari dikalangan masyarakat. ${ }^{8}$ Intinya tradisi merupakan fenomena sosial dalam kehidupan bermasyarakat yang berkembang lanjut dari perilaku lain. Tradisi ini muncul dari perkembangan perilaku masyarakat yang melakukan interaksi dan proses sosial sehingga lahir norma-norma dalam kelompok tersebut dan melembaga dilingkungan himpunan kelompok tersebut secara terstruktur. Perkembangan perilaku sosial tersebut akhirnya muncul struktur sosial yang memiliki daya ikat yang sangat kuat di dalam komunitas sosial tersebut, bahkan bisa menjadikan daya paksa dan dipandang dapat menjamin kelangsungan hidup masyarakat sesuai norma-norma yang berlaku.

Dalam menyikapi budaya yang masuk menjadi bagian agama terdapat faktor yang harus diperhatikan, yaitu adanya kaidah bahwa budaya maupun tradisi yang sudah menjadi bagian dari masyarakat dan mengakar serta diterima dikalangan suatu kelompok mayoritas muslim, maka hal itu dapat menjadi justifikasi merumuskan hukum dalam Islam. Karena hukum fiqih maupun hukum Islam adalah merupakan produk yang selalu berkembang seiring dengan perkembangan zaman dalam masyarakat. Sehingga suatu hukum Islam belum tentu cocok dengan tempat maupun era pada kalangan ummat muslim yang berbeda, kecuali dari segi universalitasnya. Oleh karena itu muncullah suatu kaidah ushul fiqih sebagai perumus hukum fiqih yang baru, jika dibutuhkan. Kaidah ushul fiqih yang dimaksud adalah:

\footnotetext{
${ }^{7}$ Nur Syam, Tarekat Petani, Fenomena Tarekat Syattariyah Lokal, (Yogyakarta: LkiS, 2013), hlm. $44-45$

${ }^{8}$ Sofyan, Kasim Yahiji, Akulturasi Islam dan Budaya Lokal, Studi Islam tentang Ritus-Ritus Kehidupan dan Tradisi Lokal Muslim Gorontalo,(Malang: Cita Intrans Selaras, 2018), hlm. 28
} 


\section{"adat istiadat dapat dijadikan pijakan hukum"}

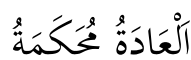

Kaidah tersebut adalah ungakapan yang paling ringkas dan mudah dipahami sekaligus ungkapan terbaik dibandingkan yang pernah dibuat ulama-ulama salaf sebelumnya. Ulama salaf terdahulu merumuskan kaidah tersebut cenderung bersifat rumit dan kurang sederhana. Adat istiadat yang dapat dijadikan pijakan hukum tersebut tenttunya merupakan suatu kebiasaan yang dilakukan secara berulang-ulang oleh sekelompok orang atau sering disebut adat jama'iyyah. Adapun jika tradisi tersebut berupa adat fardliyyah atau kebiasaan yang dilakukan oleh personal orang secara berulang maka hal tersebut tidak bisa dipandang sebagai sumber penetapan hukum Islam. ${ }^{9}$

Relasi hukum Islam dengan tradsi ini sering dikait-kaitkan dengan dua hukum yang keduanya adalah hukun yang saling bertentangan. Pertama yaitu hukum sunnah yang secara etimologi diartikan Abu al-Baqa dalam kitab kuliyyat diartikan sebagai suatu jalan walaupun tidak diridhoi oleh Allah. Sedangkan secara terminologi sunah diartikan sebagai jalan yang diridhoi Allah yang ditempuh dalam menjalankan agama, yaitu sesuatu yang pernah dilakukan Rasulullah saw dan para sahabatnya yang pandai dalam urusan agama. Karena dalam suatu Hadits Rasul saw :

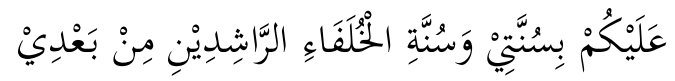

"Hendaklah kalian berpegang pada sunnahku dan sunnah khulafa' ar-rasyidin setelabku"

Dari Hadits tersebut telah jelas bahwa sunnah adalah segala sesuatu yang tidak hanya dilakukan Rasulullah saw saja, melainkan juga segala sesuatu yang dilakukan para sahabat Rasul (khulafa' ar-rasyidin). Sedangkan secara 'urf (tradisi), sunnah adalah suatu ajaran yang diikuti secara konsisten oleh para pengikut, baik nabi ataupun wali. ${ }^{10}$

Hukum yang kedua adalah bid'ah, yaitu seperti yang dijelaskan syaikh Zaruq dalam kitab Uddatul murid menjelaskan bahwa bid'ah adalah memperbaharui perkara dalam agama yang menyerupai ajaran agama itu sendiri, padahal hal tersebut bukan dari ajaran agama, baik dalam bentuk gambaran maupun dalam bntuk hakikatnya. Sebagaimana sabda nabi saw:

$$
\text { مَنِ احْدَثَ فِنْ اَمْرِنَا هَذَا لَيْنَ رِنْهُ فَهُوَ رَدُّ }
$$

"Barang siapa yang membuat-buat dalam agama kami ini (yang) bukan bagian padanya, maka hal tersebut ditolak." (HR. Bukhori, Muslim)

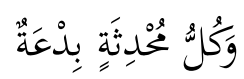

"Dan setiap hal yang dibuat-buat (dalam agama) adalah bid'ah." (HR. Nasa’, Ibnu Majah)

Para ulama telah menjelaskan bahwa pengertian kedua Hadits diatas adalah dikembalikan pada masalah hukum meyakini sesuatu (amalan) yang tidak bisa

\footnotetext{
${ }^{9}$ Muhammad Sholikin, Ritual dan Tradisi Islam Jawa, (Jakarta: Suka Buku, 2010), hlm. 24

${ }^{10}$ Muhammad Hasyim Asyari, Risalah Ahlus Sunnah Wal Jama'ah, (Jombang: Maktabah Turats Alislami, 1997), hlm. 5
} 
8 Tradisi Nahdlatul Ulama ....

mendekatkan diri kepada Allah, sebagai bisa mendekatkan diri kepada Allah bukan mutlak semua pembaharuan dalam agama. Karena mungkin saja pembaharuan terdapat contoh landasan ushulnya dalam agama, atau terdapat contoh furui'yah-nya, maka diqiyaskanlah terhadapnya. ${ }^{11}$ Berdasarkan pengertian hukum melakukan tradisi diatas kita dapat analisa hukum melaksanakan tradisi-tradisi berdasarkan adanya dalil-dalil dalam Al-Qur'an dan Hadits maupun berdasarkan kesepakatan para alim ulama dalam menghukumi pengamalan tradisi tersebut.

\section{Tradisi NU dalam Perspektif Hukum Islam}

\section{a. Pujian Diantara Adzan dan Iqomah}

Pujian adalah kata-kata mulia yang berisi do'a ataupun dakwah yang dikumandangkan diantara adzan dan iqomah. Pujian ini adalah istilah khas yang digunakan masyarakat Nahdlatul 'Ulama dalam tradisi melantunkan pujian kepada Allah, sholawat nabi, kadang juga berupa syi'ir yang berisikan pesan moral. ${ }^{12}$ Pujian-pujian ini ada yang berbahasa arab, seperti bacaan sholawat nariyah, sholawat thibbil qulub dan sholawat-shoalwat nabi yang lainnya, dan juga ada yang berbahasa jawa yang diciptakan oleh para walisongo pada waktu menyebarkan ajaran agama Islam ditanah Jawa. Dengan memasukkan syi'ir-syi' ir ini dalam menyebarkan ajaran agama Islam melalui akulturasi budaya lokal dengan ajaran Islam, walisongo berhasil menyebarkan ajaran agama Islam di bumi nusantara ini.

Adapun pujian yang isinya berdoa kepada Allah swt merupakan bentuk pengamalan dari Hadits yang diriwayatkan Ahmad, Abu Dawud, Tirmidzi, Nasa'I, dan Ibnu Hibban dari Anas ra.:

$$
\text { الدُعَاءُ لَايُرَدُ بَيْنَ الَأَذَاِِِ وَالْإِقَامَةِ }
$$

"Do'a setelah adzan dan iqomah tidak ditolak"(HR. Ahmad, Abu Dawud, Tirmidzi, Nasa'I) ${ }^{13}$

Dengan adanya dalil tersebut maka sudah jelas bahwa memanjatkan doa setelah adzan dan iqomah hukumnya adalah boleh. Dan Hadits tersebut adalah Hadits shohih, maka dalil tersebut dapat dijadikan dasar diperbolehkannya melantunkan doa. Adapun pujian yang berisi sholawat diantara adzan dan iqomah juga ada dalil pendukung atas diperbolehkannya, yaitu Hadits riwayat Muslim

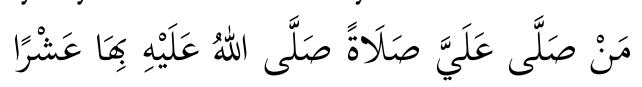

"Barang siapa yang bersholawat kepadaku sekali maka Allah bersholawat kepadanya sepuluh kali." (HR. Muslim). ${ }^{14}$

\footnotetext{
${ }^{11}$ Ibid., hlm. 6

${ }^{12}$ Sukarja Salam, dkk, Ke-NU-an, Ahlussunnah Waljamaah An-Nadhdliyyah untuk Kelas 12 Madrasah Aliyah, (Yogyakarta: Lembaga Pendidikan Ma'arif NU DIY, 2017), hlm. 164

${ }^{13}$ Marzuqi Mustamar, Al-Muqtathofat Liahli Al-Bidayat, (Malang: Muara Progresif, 2007), hlm.

${ }^{14}$ Ibid., hlm.
} 
Dari dua dalil-dalil tersebut telah jelas diperbolehkannya melantunkan pujian kepada Allah dan bersholawat kepada Nabi Muhammad saw setelah adzan dan sebelum iqomah. Dan dalam suatu riwayat diterangkan pada suatu saat sahabat umat bertakbir di dalam masjid mina dan orang-orang yang didalam masjid tersebut ikut bertakbir mengikuti umar, sehingga pasar-pasar di Mina tutup karena takbir itu. Suara takbir tersebut terdengar hingga ke Masjidil Haram, maka para jamaah di Masjidil Haram ikut menyerukan takbir Bersama sahabat Umar ra. ${ }^{15}$

\section{b. Pembacaan Sholawat Nabi dan Dziba'an}

Bersholawat adalah bentuk kecintaan kita kepada Nabi Muhammad saw yang dianjurkan Allah swt kepada umat Islam. Kata sholawat brasal dari bahasa Arab yaitu bentuk jamak dari kata shalla yang berarti doa, keberkahan, kemuliaan, kesejahteraan, dan ibadah. Bersholawat dapat diartikan ditinjau dari pelakunya. Jika sholawat datangnya dari Allah swt berarti memberi rahmat kepada makhluk. Sholawat dari malaikat berarti istighfar (memberikan ampunan). Sedangkan sholawat dari orang-orang yang beriman berarti do'a atau bentuk doa makhluk kepada Allah swt agar memberi rahmat serta kesejahteraan kepada Nabi Muhammad saw dan keluarganya. Sholawat juga bisa berarti doa kita kepada Allah kepada diri sendiri maupun kepada orang banyak. Sholawat juga bisa dijadikan sebagai ibadah dengan tujuan mendapatkan pahala kepada-Nya, sebagamana janji Nabi Muhammad saw, bahwa barang siapa yang bersholawat kepadanya maka akan diberiakan pahala yang besar oleh Allah swt, baik sholawat itu berupa ucapan lisan, tulisan maupun batin. ${ }^{16}$

Hukum bersholawat telah jelas ditetapkan oleh Allah dalam firman-Nya surah Al-Ahzab ayat 56

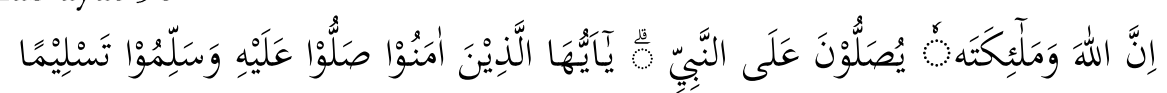

"Sesungguhnya Allah dan para malaikat-Nya bersholawat untuk Nabi. Hai orangorang yang beriman, bersholawatlah kamu untuk Nabi dan ucapkan salam penghormat kepadanya." (QS. Al-Ahzab ayat 56) ${ }^{17}$

Diba'an meupakan kegiatan pembacaan kitab yang berisikan puji-pujian kepada Rasulullah saw, kisah-kisah perjalanan, keturunan dan sifat-sifat mulianya. Kitab ini dikarang oleh Syaikh Wajihuddin Abdurrahman bin Ali bin Muhammad al-Syaibani al-Yamani al-Zabidi asy-Syafi'i. Beliau masyhur dengan nama al-Diba'i. Lahir di Yaman pada bulan Muharram $866 \mathrm{H}$ dan wafat pada hari Jumat tanggal 12 Rajab tahun $944 \mathrm{H}$. dia termasuk penganut ahlussunnah waljamaah. Di dalam kitab al-Diba'i terdapat kisah Rasulullah di masa kehidupan beliau, diantaranya pada peristiwa hijarah ke Madinah dan disambut oleh sahabat kaum Anshor di Madinah. Di tengah-tengah pembacaan maulud al-Diba'i biasanya terdapat suatu

\footnotetext{
${ }^{15}$ Sukarja Salam, dkk, Op. Cit., hlm 165

${ }^{16}$ Sukarja Salam, dkk, Op. Cit., hlm. 168

${ }^{17}$ Departemen Agama RI, Al-Qur'an dan Terjemah, (Jakarta: Syaamil Quran, 2009)
} 
acara dimana para pembaca berdiri dan membayangkan kedatangan Rasulullah saw disaat mahalul qiyam. Kemudian membacakan maulid al-Barzanji dengan berdiri. Pengarang Barzanji adalah Ja'far al-Barzanji al-Madani, seorang khatib di Masjidil Harom dan seorang mufti dari kalangan Syafi'iyah. Wafat di Madinah pada tahun 1177 H. Dengan pembacaan maulid nabi ini kita berharap, kita bisa bersama dengan Rasulullah saw. Di samping iru dibaan bisa menyatukan tali silaturrahmi antar warga Nahdliyyin. Pembacaan maulid ini biasa dibacakan pada hari Kamis malam Jumat, malam Senin, pada bulan Rabiul Awal, dan pada acara-acara tertentu. ${ }^{18}$

\section{c. Yasinan dan Tahlil}

Berkumpul untuk melaksanakan kegiatan yasinan tan tahlil secara bersamasama adalah suatu perkara yang tidak pernah dilakukan pada zaman hidupnya Rasulullah saw. Hal tersebut adalah kegiatan bid'ah (rekayasa), tetapi termasuk dalam bid'ah hasanah (rekayasa baik). Bid'ah tersebut terletak pada berkumpulnya para jamaah secara masal, bukan terletak pada bacaan yang dibaca pada majlis tersebut. Bacaan-bacaan yang dibaca merupakan bacaan yang ada dan dianjurkan oleh Rasulullah saw dalam Haditsnya. Bacaan surah Yasin dan tahlil ini dilaksanakan oleh warga Nahdliyyin sebagai hadiah kepada orang yang telah wafat. Serangkaian bacaan tersebut antara lain surah Al-Fatihah, Al-Baqoroh, Ayat Kursi, Al-Ikhlash, Al-Falaq, An-Nas, dan kalimat tayyibah pilihan, diantaranya tahlil, tasbih, sholawat dan lain-lain dilanjutkan dengan pembacaan doa kepada ahli kubur, dan mohon ampunan dosa kepada orang muslim. ${ }^{19}$ Adapun dalil yang mendasari amaliyah ini antara lain:

$$
\text { من قرا سورة يس والصفات ليلة الجمعة اعطاه الله سؤله }
$$

"Barangsiapa membaca surah Yasin dan al-Saffat di malam Jumat, Allah mengabulkan permintaannya." (HR. Abu Daud dari al-Habr)

$$
\text { قأل رجل النبي صل الله عليه وسلم فقال يا رسول الله إن أمي ماتت افينفعها ان تصدقت عنها ؟ }
$$

"Bertanya seorang laki-laki kepada Nabi saw: Ya Rasulallah sesungguhnya ibu saya telah mati, apakah berguna bagi saya,seandainya saya bersedekah untuknya? Rasulullah menjawab: Ya berguna untuk ibumu." (HR. Abu Dawud)

Dari kedua hadits tersebut bahwa amaliyah pembacaan Yasin dianjurkan oleh Rasulullah saw kepada umatnya dan ada riwayat-riwayat lain dianjurkannya membaca kalimat-kalimat tayibah. Penghadiaahan pembacaan ayat-ayat tersebut berdasarkan hadits di atas berguna untuk para ahli kubur yang kita doakan. Adapun makanan-makanan yang dihidangkan oleh si pembuat hajat bukanlah esensi dari

\footnotetext{
${ }^{18}$ Sukarja Salam, dkk, Op. Cit., hlm. 191

${ }^{19}$ Ahmad Shihabuddin, Membongkar Kejumudan: Menjawab Tuduhan-Tuduhan Salafi Wahabi, (Jakarta: Noura Books, 2014), hlm. 164
} 
pelaksanaah tahlilan. Itu hanyalah sebagai bentuk sedekah sahibul hajat kepada tamu dan tidak merupakan keharusan. Jika memang tidak mampu dan tidak ada biaya, sangat tidak dianjurkan untuk menjamu para tamu. Dan juga tidak dianjurkan mengadakan jamuan yang mewah. ${ }^{20}$

\section{d. Ziarah Kubur}

Ziarah kubur merupakan salah satu dari tradisi warga Nahdliyyin, yaitu mengunjungi makam para kerabat, guru, maupun wali yang telah meninggal mendahului kita. Dalam tradisi ziarah kubur ini warga Nahdliyyin tidak hanya untuk menengok atau mengunjungi kubur, melainkan juga untuk mendoakan kepada yang dikubur, khususnya orang muslim dan mengirimkan pahala untuknya atas bayaan ayat-ayat suci Al-Qur'an dan kalimat-kalimat tayibah, seperti tahlil, tasbih, tahmid, sholawat dan lain sebagainya. Pada awalnnya praktek ziarah kubur ini pernah dilarang oleh Rasulullah saw kepada umat islam karena banyak kemadhorotan yang terjadi ketika hal tersebut dilaksanakan, akan tetapi setelah akidah umat islam menjadi kuat dan tidak ada kekhawiran untuk berbuat syirik, praktek ziarah kubur ini diperbolehkan kembali. ${ }^{21}$ Seperti pada Hadits yang diriwayatkan oleh Ahmad, Muslim, dan Ashabussunan dari Abdullah bin Buraidah yang diterima oleh bapaknya bahwa Nabi saw bersabda:

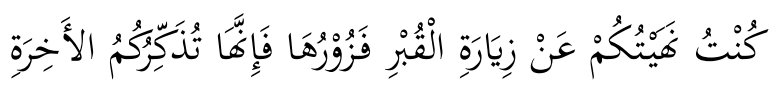

"Dahulu saya melarang menziarahi kubur, adapun sekarang berziarahlah kesana, karena yang demikian itu akan mengingatkanmu akan hari akhir. (HR. Ahmad, Muslim, dan Ashabussunan)

Dalam kitab Ma'rifatu Al-Sunnah wa Al-Atsar jilid 3 hal. 203, Imam Syafi'i berkata, "ziarah kubur hukumnya tidak apa-apa (boleh). Namun, sewaktu menziarahi kubur, hendaknya tidak mengatakan hal-hal yang menyebabkan murka Allah.” Dan Syaikh Mansur Ali Nashif dalam kitab Al-Taju Al-Jami' li Al-Ushul jilid 1 hal. 381 menyatakan, "Menurut mayoritas Ahlu Sunnah, dinyatakan bahwa ziarah kubur adalah sunnah." Dari Hadits dan maqolah-maqolah tersebut jelas bahwa ziarah kubur merupakan sunnah Nabi saw yang didalamnya bermanfaat guna menginagtkan kita tentang kematian dan hari akhir. ${ }^{22}$ Ziarah kubur ini biasa dilakukan warga Nahdliyyin pada kamis sore, pada permulaan bulan Ramadhan, pada hari terakhir bulan Ramadhan maupun dihari-hari biasa.

\section{Kesimpulan}

Tradisi keberagamaan masyarakat Nahdlatul Ulama adalah sebuah tradisi yang didasarkan pada ajaran agama Islam. Tradisi-tradisi tersebut tentu memiliki dalil dasar bisa diperbolehkannya ataupun dalil kesunnahan melakukan amaliyah-amaliyah tersebut.

\footnotetext{
${ }^{20}$ Ahmad Shihabuddin, Ibid., hlm. 165

${ }^{21}$ Sutejo ibnu Pakar, Panduan Ziarah Kubur, (Cirebon: Kamu NU, 2015), hlm. 37

${ }^{22}$ Ahmad Shihabuddin, Op. Cit., hlm. 128
} 
12 Tradisi Nahdlatul Ulama ....

Dalam tradisi NU tersebut, ditanamkan rasa kebersamaan sehingga dengan menjalankan tradisi-tradisi tersebut dapat mempererat tali silaturrahmi antar warga Nahdliyyin. Tradisitradisi ini didapatkan dari proses pribumisasi yang mana kegiatan keberagamaan dipadukan dengan budaya di ruang lingkup warga Nahdliyyin yang hukumnya telah diperbolehkan ataupun disunnahkan dalam pelaksanaannya melalui dalil dalam Al-Quran, Hadits, ijma' maupun qiyas. Adapun tradisi-tradisi NU yang khas seperti ; pujian diantara adzan dan iqomah, ziarah kubur, diba'an, yasinan dan tahlilan. Tradisi-tradisi NU seperti inilah yang sering disebut bid'ah karena tidak pernah dilakukan pada masa Rasulullah Saw. Meskipun demikian, tradisi-tradisi tersebut memiliki landasan dalil dan merupakan bid'ah yang baik (bid'ah hasanah).

\section{Daftar Pustaka}

Asyari, Muhammad Hasyim. 1997. Risalah Ahlus Sunnah Wal Jama'ah. Jombang: Maktabah Turats Al-islami.

Bruinessen, Martin van. 2008. NU, Tradisi, Relasi-Relasi Kuasa, Pencarian Wacana Baru. Yogyakarta: LKiS.

Burhani, Ahmad Najib. 2019. Menemani Minoritas: Paradigma Islam tentang Keberpihakan dan Pembelaan kepada yang Lemah. Jakarta: Gramedia.

Departemen Agama RI. 2009. Al-Qur'an dan Terjemah. Jakarta: Syaamil Quran.

Firdaus, Salsabila, dan Ulfah Rahmawati. 2013. "Hadis dalam Tradisi Nahdlatul Ulama: Studi atas Pemahaman Hadis Lajnah Bahtsul Masa'il.” ADDIN 7:425-38.

Kadir, Muslim A. 2003. Ilmu Islam Terapan. Yogyakarta: Pustaka Pelajar.

Kadir, Muslim A. 2011. Dasar-Dasar Keberagamaan dalam Islam. Yogyakarta: Pustaka Pelajar.

Lutfi, Khabibi Muhammad. 2016. "Islam Nusantara: Relasi Islam dan Budaya Lokal." SHAHIH 1:1-12.

Pakar, Sutejo Ibnu. 2015. Panduan Ziarah Kubur. I. Cirebon: Kamu NU.

Salam, Sukarja, Sigit Purnama, dan Poniji. 2017. Ke-NU-an, Ahlussunnah Waljamaah AnNadhdliyyah untuk Kelas 12 Madrasah Aliyah. Yogyakarta: Lembaga Pendidikan Ma'arif NU DIY.

Shihabuddin, Ahmad. 2014. Membongkar Kejumudan: Menjawab Tuduhan-Tuduhan Salafi Wahabi. Jakarta: Noura Books.

Sholikin, Muhammad. 2010. Ritual dan Tradisi Islam Jawa. Yogyakarta: Narasi.

Sofyan, dan Kasim Yahiji. 2018. Akulturasi Islam dan Budaya Lokal, Studi Islam tentang Ritus-Ritus Kehidupan dan Tradisi Lokal Muslim Gorontalo. Malang: Cita Intrans Selaras.

Syam, Nur. 2013. Tarekat Petani, Fenomena Tarekat Syattariyah Lokal. Yogyakarta: LKiS.

Wahid, Abdurrahman. 2011. Islamku Islam Anda Islam Kita: Agama Masyarakat Negara Demokrasi. Jakarta: Democrasi Project.

Zahra, Ahmad. 2004. Tradisi Intelektual NU. Yogyakarta: LKiS. 